\title{
Management response to eWOM in rural lodging establishments
}

\section{Respuesta empresarial al eWOM en alojamientos de turismo rural}

\author{
Rosa M. Hernández-Maestro \\ Department of Administration and Business Economics and IME, \\ University of Salamanca, Salamanca, Spain
}

\begin{abstract}
Purpose - Companies are adopting a more active role in managing their online reputations by using electronic word of mouth (eWOM) and often responding directly to customer reviews. Therefore, companies need to understand the effects of management responses to customer reviews. This study aims to explore whether it is worth responding to reviews and whether expressing gratitude enhances the effects of review responses.

Design/methodology/approach - This study uses customer reviews and management response data from a sample of 766 Spanish rural lodging establishments listed on Toprural (www.toprural.com). Analyses are undertaken with NVivo and SmartPLS.

Findings - Responding to negative reviews improves lodging establishments' average ratings, but responding to positive reviews has no significant direct effect. Expressing gratitude in responses positively moderates the effects of review responses; this moderating effect is more significant for responses to negative than to positive reviews.

Originality/value - Previous research provides contradictory evidence about the positive outcomes of a company's responses; it also does not address expressions of gratitude. This research provides evidence of the direct effects of management response quantity on ratings. It also expands current research on the content characteristics of these responses. The contextual setting for this research, rural tourism, is a key driver of sustainable rural development and a sector in which eWOM is especially relevant; thus, correctly managing the eWOM phenomenon becomes crucial.
\end{abstract}

Keywords eWOM, Management response, Online reputation, Rural tourism

Paper type Research paper

\section{Resumen}

Propósito - Al objeto de mejorar su reputación online, las empresas progresivamente están adoptando un papel más activo ante las reseñas online de los clientes, ofreciendo respuestas online a dichas reseñas. Por tanto, es necesario que las empresas conozcan mejor los efectos de responder online. Este estudio examina si resulta beneficioso responder a las reseñas y si expresar agradecimiento potencia el efecto de responder.

(c) Rosa M. Hernández-Maestro. Published in Spanish Journal of Marketing - ESIC. Published by Emerald Publishing Limited. This article is published under the 646389 Creative Commons Attribution (CC BY 4.0) licence. Anyone may reproduce, distribute, translate and create derivative works of this article (for both commercial and non-commercial purposes), subject to full attribution to the original publication and authors. The full terms of this licence may be seen at http:// creativecommons.org/licences/by/4.0/legalcode

Support was received from Toprural, which provided the data used in this research. This work was also supported by the Ministry of Economy and Competitiveness (Spain), project ECO2017-82107-R.
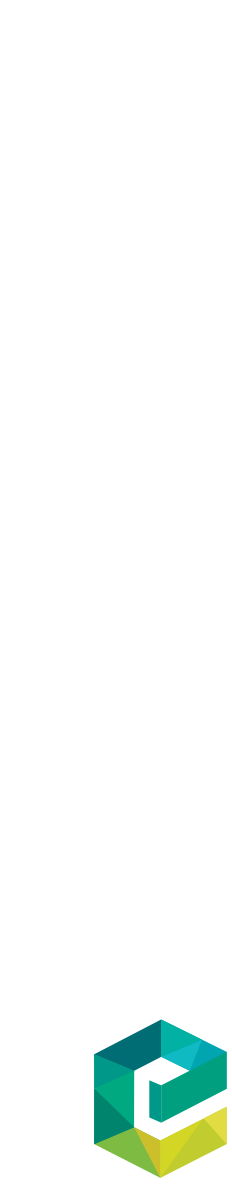
Diseño/metodología/enfoque - A partir de datos sobre reseñas online de clientes y respuestas de la empresa, correspondientes a una muestra de 766 alojamientos de turismo rural de Toprural (www.toprural. com), se realizan análisis con NVivo y SmartPLS.

Resultados - Responder a reseñas negativas mejora las puntuaciones medias del establecimiento en Toprural. Sin embargo, responder a reseñas positivas no tiene un efecto directo significativo. Además, expresar agradecimiento en las respuestas modera positivamente el efecto de responder. No obstante, esta moderación es más intensa en el caso de respuestas a reseñas negativas frente a las reseñas positivas.

Originalidad/valor - La investigación previa aporta evidencia contradictoria sobre los efectos de la intensidad de respuesta empresarial a las reseñas online; además, no se ocupa de la expresión de gratitud en particular. Este estudio aporta luz respecto al efecto directo de la intensidad de respuesta sobre las puntuaciones online y amplía la investigación actual sobre las características de contenido de las respuestas. El marco de estudio, el turismo rural, se considera clave para un desarrollo rural sostenible y constituye un escenario donde el boca-oído electrónico es especialmente importante; en consecuencia, gestionar correctamente el fenómeno es crucial.

Palabras clave Boca-oído electrónico, Respuesta empresarial, Reputación online, Turismo rural

Tipo de artículo Trabajo de investigación

\section{Introduction}

The growing importance of the Internet and the development of devices that access it (e.g., smartphones, tablets) have jointly contributed to the increasing importance of electronic word of mouth (eWOM). When consumers are involved in a buying decision process, they often conduct online searches (e.g., blogs, forums, content sharing websites) to get information regarding products (Browning et al., 2013; Xie et al., 2017). Thus, a company's eWOM exerts an impact on its reputation (Browning et al., 2013; Nieto et al., 2014). In particular, eWOM informs consumers' service quality perceptions and behaviors during the buying decision process (Browning et al., 2013; Filieri and McLeay, 2013), largely because consumers consider eWOM more relevant than communication provided by the companies, with its commercial purposes (Bickart and Schindler, 2001). Consumers might anticipate that companies disguise negative features of their products (Park et al., 2007), whereas eWOM appears more trustworthy because it is provided by customers who have consumed the product and is independent of the company's marketing actions (Sparks et al., 2013). Thus, a company's website might be enriched by the inclusion of customers' informationexchange, as information that complements marketing content. However, eWOM about a company or product also appears on various websites, beyond the company's, which makes monitoring eWOM very complicated.

Yet managing eWOM correctly is increasingly important, especially in the hospitality industry. First, the phenomenon has expanded in service settings whose experience-based products are difficult to evaluate prior to consumption (Litvin et al., 2008). For example, hospitality consumers cannot predict product quality until they arrive at the booked lodgings. The product thus is perceived as high risk, which increases the importance of interpersonal influences. As a consequence, consumers turn to eWOM for guidance because the information reduces the degree of perceived uncertainty they suffer (Ye et al., 2009, 2011; Papathanassis and Knolle, 2011; Mauri and Minazzi, 2013). Online travel platforms accordingly provide consumer reviews (e.g., Booking.com, Expedia Group and TripAdvisor); a recent report by TripAdvisor (2019), one of the world's largest travel platforms, indicates that $81 \%$ of surveyed respondents reported that they always or frequently read online reviews before booking hotels. Second, measures related to eWOM 
(e.g., review valence, review volume) align well with measures of business performance in hospitality, such as occupancy rate, bookings, and revenue per available room (RevPAR) (Ye et al., 2009; Viglia et al., 2016; Phillips et al., 2017). Third, hospitality, products are seasonal and perishable, increasing marketing stress levels for companies. Fourth, hospitality is an extremely competitive industry. Correctly managing eWOM might provide important competitive advantages: it is a cost-effective means to learn customers' perceptions and needs and manage online reputations (Litvin et al., 2008; Bughin et al., 2010; Ye et al., 2011; Mate et al., 2019).

Considering the importance of eWOM, responding to online customer reviews is widely regarded as a tool that supports reputation management and might reinforce or rebuild company reputations (Lee and Song, 2010; Wei et al., 2013; Willemsen et al., 2013; Lee and Blum, 2015; Sparks et al., 2016; Proserpio and Zervas, 2017; Mate et al., 2019; Zhang et al., 2020). In particular, management responses can be used as an instrument for service recovery (Hennig-Thurau et al., 2010; Wei et al., 2013; Gu and Ye, 2014; Lee and Blum, 2015; Min et al., 2015; Sparks et al., 2016; Sparks and Bradley, 2017; Mate et al., 2019; Zhang et al., 2020) and customer relationship management (Hennig-Thurau et al., 2010; Wei et al., 2013; Zhang et al., 2020). Both service recovery and customer relationship management are assumed to favor reputation (Lee and Blum, 2015; Zhang et al., 2020). Indeed, it is common for professional operators, such as Google or TripAdvisor, to recommend that businesses respond to customer reviews. In fact, a study by TripAdvisor (2015) reported that $65 \%$ of respondents agreed that they were more likely to book a hotel that responded to traveler reviews.

Hospitality research attributes several positive consequences to the quantity of eWOM management responses. Specifically, response quantity positively influences consumer perceptions and subsequent behavior (Xie et al., 2016; Proserpio and Zervas, 2017), though not all studies observe a significant positive effect of response quantity on consumer perceptions (Mauri and Minazzi, 2013). Nonetheless, empirical evidence indicates that the content of the response is a key element regarding the efficacy of the responses (Wei et al., 2013; Lee and Blum, 2015; Sparks et al., 2016; Sparks and Bradley, 2017; Zhang et al., 2020).

Thus, additional knowledge about the topic is needed. First, understanding the consequences of response quantity would be valuable. Second, providing information about the most effective response content would be useful; the issue constitutes a challenge for research about eWOM nowadays. Third, no studies have addressed the effect of management responses on rural lodging establishments. These establishments are crucial for rural development, so studies that suggest ways for them to perform more effectively are necessary and relevant (Hernández-Maestro and González-Benito, 2014). Fourth, as with all lodgings, customers increasingly consult online reviews for information about rural lodging establishments (Observatorio del Turismo Rural, 2017) and empirical evidence shows that customer reviews influence rural lodging establishments' performance (Nieto et al., 2014; Melo et al., 2017). Therefore, this research examines the direct effects of management response quantity on the average ratings of rural lodging establishments and the moderating role of expressing gratitude in responses. To understand both the direct and moderating effects, responses to negative reviews and positive reviews are studied separately.

Accordingly, Section 2 reviews the growing importance of eWOM. The hypotheses predict the effects of response quantity and management expressions of gratitude in those responses. After detailing the methodology in Section 3 and the results in Section 4, this 
SJME

24,2

article concludes with some discussion, implications, limitations, and further research directions in Section 5.

\section{Conceptual framework \\ 2.1 Electronic word of mouth eWOM refers to:}

[...] any positive or negative statement made by potential, actual, or former customers about a product or company, which is made available to a multitude of people and institutions via the Internet (Hennig-Thurau et al., 2004, p. 39).

The Internet enables users to express their opinions about products easily and many websites encourage customers to evaluate products (e.g., social media, blogs, and discussion forums). This article in particular focuses on guest reviews on an accommodation booking website.

A key difference between word of mouth (WOM) and eWOM is that WOM implies contact between people who already know one another (e.g., family, friends), whereas eWOM often occurs among people who do not know one another. In this respect, although many reviews are anonymous, they often include the reviewer's profile information, which helps readers interpret the reviews (Nieto et al., 2014). Moreover, reviews often remain on websites for a long time, exerting a lasting impact on a company's reputation (Hennig-Thurau et al., 2004).

The influence of eWOM on decision-making appears to be increasing progressively, especially in service industries such as hospitality (Mate et al., 2019). This relevance of eWOM for hospitality is supported by current industry figures about use intensity. In this regard, major professional operators (TripAdvisor, HomeAway) periodically carry out studies regarding the importance of the eWOM phenomenon. As noted previously, in a recent report from TripAdvisor (2019), 81\% of those surveyed indicated that they always or frequently read online reviews before booking hotels; a HomeAway (2019) study also affirms that $50.2 \%$ of stays in tourist houses (e.g., apartments, villas, bungalows) in Spain produced at least one new online review in 2018. This popularity of online reviews has caused many researchers to focus on related topics and propose measures of eWOM (e.g., review valence, review volume), as important cues that affect consumers' perceptions and behaviors during decision-making processes (Vermeulen and Seegers, 2009; Browning et al., 2013; Filieri and McLeay, 2013; Mauri and Minazzi, 2013). Besides, measures of eWOM have been found to favor performance (e.g., occupancy rate, bookings, revenue, profitability) in hospitality settings (Ye et al., 2009; Viglia et al., 2016; Phillips et al., 2017; Zhang et al., 2019; Anagnostopoulou et al., 2020) and in rural lodging establishments in particular (Nieto et al., 2014; Melo et al., 2017).

Both signaling theory (Akerlof, 1970) and attribution theory (Kelley, 1973) also offer explanations for the importance of eWOM. According to signaling theory, consumers use signals, including eWOM, to reduce the risk implicit to purchasing processes. In particular, a higher volume of reviews has been associated with greater market awareness and, consequently, decreased risk because more people have bought the product. Ratings might also provide cues to help people form expectations about service quality (Browning et al., 2013; Mauri and Minazzi, 2013). Then, attribution theory describes how people derive conclusions from others' behaviors. When exposed to a review, a reader's perception and behavior vary with what can be subjectively derived from the review, its relevance and usefulness, and the reason the 
author wrote the review. If a review contains a narrated problem, a reader also infers who is responsible for the problem, its stability, and so forth (Sen and Lerman, 2007; Libai et al., 2010; Browning et al., 2013; Filieri and McLeay, 2013).

Management response to eWOM

\subsection{Management response quantity and ratings}

Management responses refer to online responses to customer reviews posted directly by the management of the company. The online management response is not only visible to consumers who wrote the reviews but also to all future consumers who visit the website. Thus, such responses to online customer reviews are widely regarded as tools that support reputation management, by reinforcing or rebuilding a reputation (Lee and Song, 2010; Wei et al., 2013; Lee and Blum, 2015; Sparks et al., 2016; Proserpio and Zervas, 2017; Zhang et al., 2020). In particular, to promote online reputations, management responses can be used as instruments for service recovery or customer relationship management (Lee and Blum, 2015; Zhang et al., 2020).

When a service failure occurs, customers want to understand what went wrong, why and what is being done about it. Thus, responding to negative reviews offers the opportunity to apologize, provide explanations, or offer financial compensation (e.g., discounts on future services) (Wei et al., 2013; Gu and Ye, 2014; Lee and Blum, 2015; Min et al., 2015; Sparks et al., 2016; Sparks and Bradley, 2017; Mate et al., 2019; Zhang et al., 2020). In addition, management responses can facilitate customer relationship management; through the act of responding online, the company directly interacts with customers (e.g., showing appreciation, inviting the guest to return) (Wei et al., 2013; Zhang et al., 2020).

In this context, hospitality research has attributed several positive consequences to the quantity of management responses. Specifically, response quantity positively influences customers' perceptions and subsequent behavior, benefiting both ratings and review volume (Xie et al., 2016; Li et al., 2017; Proserpio and Zervas, 2017). Providing no response at all instead negatively affects hotels' online ratings (Anderson and Han, 2016). Both review ratings and review volume are important cues for customers (Vermeulen and Seegers, 2009; Browning et al., 2013; Filieri and McLeay, 2013; Mauri and Minazzi, 2013). Thus, response quantity also has been positively linked to hotels' bookings and revenue (Anderson and Han, 2016; Xie et al., 2016; Lui et al., 2018).

Active listening theory (Drollinger et al., 2006) and signaling theory (Akerlof, 1970) provide theoretical support for the positive outcomes of management responses. According to signaling theory, consumers look for signals to reduce the uncertainty implicit in the purchase process. Active listening by a company involves sensing, processing, and responding; if the firm does not provide a response though, customers cannot know that the company has engaged in such sensing and processing (Drollinger et al., 2006; Min et al., 2015; Liu and Ji, 2019). Thus, a management response offers a signal to consumers that the company is actively listening, so it appears to care about customers and take their online reviews into account.

Several arguments support the positive effects of management response quantity on company ratings. First, it has a positive influence on consumer perceptions about a hotel's trustworthiness and the extent to which the hotel cares about customers (Sparks et al., 2016), which should benefit the hotel's reputation. Reputation might positively influence (or bias) the hotel's future ratings. For example, consumers who have developed such positive perceptions might overlook service failures (Browning et al., 2013; Ullrich and Brunner, 2015). Second, when businesses respond, the cost to the customer of formulating a negative review increases because customers expect 
SJME

24,2

268

that the review will be closely examined, so they are less likely to write inexact or false-negative reviews (Proserpio and Zervas, 2017). Third, customers will be more motivated to express positive reviews if they perceive that the company pays attention to them (Proserpio and Zervas, 2017). Fourth, when the response to a negative review satisfies the customer, he or she might return and then write a new, positive review. That is, service recovery might transform a previously dissatisfied customer into a loyal customer (Lee and Song, 2010; Willemsen et al., 2013; Gu and Ye, 2014).

Industry figures also indicate the importance of responding to reviews. Medallia (2015) reveals that highly responsive properties receive higher customer satisfaction ratings than less responsive properties. Accommodations that respond to more than $50 \%$ of reviews increase their occupancy at more than twice the rate of properties that tend to ignore reviews (Medallia, 2015). In addition, a study by TripAdvisor shows that $65 \%$ of participants agreed that they were more likely to book a hotel that responded to travelers' reviews; and that four out of five TripAdvisor users believed that hotels that responded to reviews cared more about their guests. Moreover, $85 \%$ of participants agreed that a thoughtful response to a bad review would improve their impression of a hotel (TripAdvisor, 2015). A ReviewPro (2015) study reveals a link between management response rates and a measure of the online reputation of luxury hotels.

Despite some existing literature that explores and identifies the positive consequences of management response quantity, other contributions do not find these positive effects. For example, Mauri and Minazzi (2013) do not find a significant effect of response quantity on consumer expectations and instead identify a negative influence on purchasing intentions. Also, management response volume does not relate to online hotel bookings on Expedia's website (Zhang et al., 2019). Therefore, additional research is needed to understand the potential positive effects of management responses, especially in the context of rural lodging establishments, for which no studies empirically analyze this issue. Thus, the following hypotheses are formulated:

H1. Management responses to negative reviews increase the company's average rating.

H2. Management responses to positive reviews increase the company's average rating.

\subsection{The moderating role of expressing gratitude in responses}

Complementarily, both signaling theory (Akerlof, 1970) and attribution theory (Kelley, 1973) have been proposed to help to shed some light on the findings in relation to the effects of management response quantity. In this regard, management response effectiveness differs depending on what customers - past, current, and future perceive as the motivation for management responses. Response content largely determines those perceptions. Therefore, both the act of responding and the response content offer signals to consumers. Hence, a response to a negative review could be perceived as an attempt to increase sales, without any interest in satisfying the customer (Sparks et al., 2016). That is, if the response does not appear appropriate to the customer, the response might reduce a company's credibility (Ullrich and Brunner, 2015; Xie et al., 2017; Mate et al., 2019). In contrast, if the response is appropriate, the effect of responding might be enhanced because the response is perceived more favorably (Wei et al., 2013; Min et al., 2015; Sparks et al., 2016; Zhang et al., 2020). 
Several response characteristics have been studied in prior research. Min et al. (2015) show that empathetic responses, in which the manager expresses understanding of how the reviewer thinks, are perceived more favorably by customers. In addition, Sparks et al. (2016) find that the use of a "human voice" in the response (e.g., inclusion of names of the customer, employee or manager; use of the first person) vs a "professional voice" is more effective at conveying positive customer inferences (trustworthiness and company's concern). Consistently, when faced with a negative review, a specific, personalized response that relates to the content included in the customer review is also perceived more favorably by customers (Wei et al., 2013; Min et al., 2015; Zhang et al., 2020). In contrast, as Zhang et al. (2019) show, when all of a hotel's responses are similar, it negatively affects hotel bookings.

In this context, according to relationship marketing literature, customers want to feel valued (Fazal-E-Hasan et al., 2017); customer appreciation expressed by companies thus is important to business success, especially in competitive markets (Wali and Opara, 2013; Sparks and Bradley, 2017; Mate et al., 2019). In particular, studies recommend adding expressions of gratitude to customer review responses (Sparks and Bradley, 2017; Mate et al., 2019). Expressing gratitude also improves well-being for both expressers and recipients (Kumar and Epley, 2018). Therefore, companies that express gratitude in online review responses should evoke greater positive consequences by responding to reviews. In turn, the following hypotheses are formulated:

H3. When expressing gratitude, management responses to negative reviews increase their positive effect on the company's average rating.

H4. When expressing gratitude, management responses to positive reviews increase their positive effect on the company's average rating.

\section{Methodology}

\subsection{Contextual setting}

The rural lodging establishment industry has grown quickly in Spain, playing a significant role in rural economies (Hernández-Maestro and González-Benito, 2014). The number of rural lodging establishments in Spain has grown from 5,497 in 2001 to 16,660 in 2018. In addition, 4,260,670 travelers stayed in Spanish rural lodging establishments in 2018, totaling 11,457,707 overnight stays and an average stay length of 2.69 days. Of these guests, $79.71 \%$ were residents and $20.29 \%$ were nonresidents (Instituto Nacional de Estadística, INE, 2019).

Spanish rural lodging facilities comprise a wide range of types, including rural hotels (some of which are antique palaces), apartments, houses located on farms, and houses in small towns or the countryside. Regardless of the lodging type, two characteristics are common among these facilities: they retain the traditional architecture of the area and they are small. Most are family businesses and might represent supplementary income, beyond what the family earns from agriculture, commercial, or construction activities. Many lodging owners diversified their primary income sources in response to incentives promoted by the Public Administration of Spain to start rural lodging establishments. The size of facilities are limited by regulations that differ regionally and by categorization. Most rural lodging establishment owners manage all tasks related to their businesses and few have managerial education or experience in areas such as marketing and cost control. Even with the many different regional types, two general categories of establishments can be defined, namely, those that rent individual rooms and those that rent the entire 
SJME

24,2

\section{0}

establishment as a whole. Furthermore, most facilities organize complementary activities that involve contact with nature or traditional ways of life (e.g., horseback riding, excursions, traditional cooking).

Because of the importance of these rural lodging establishments in fostering local economies, they offer a compelling setting for research into how to manage eWOM. This sector is characterized by limited resources, so managing eWOM represents a valuable, low-cost method to increase online reputations and financial performance (Litvin et al., 2008; Nieto et al., 2014; Melo et al., 2017). In rural tourism, consumers rely substantially on online reviews. Specifically, $41 \%$ of rural travelers consider reviews important (Observatorio del Turismo Rural, 2017). Apart from the common features that rural lodging establishments have with other types of lodgings (experiential, seasonal and perishable products), there is an additional reason behind the great use of eWOM by rural lodging establishments' consumers: quality assurance systems within the rural sector, in contrast with those for hotels, vary widely, which makes it difficult for consumers to derive clear conclusions from each quality distinction (Nieto et al., 2014).

\subsection{Data collection}

The research data came from Toprural (www.toprural.com), pertaining to Spanish rural lodging establishments. Toprural is the leading accommodation booking website in Spain, specialized in rural lodging establishments and is a subsidiary of HomeAway Spain, S.L. It allows customers to provide reviews (e.g., ratings, comments, pictures, and videos) related to their previous bookings. The data $\mathrm{c}$ over the period from 2008-2010. After the database preparation (e.g., removing duplicate cases, blank cases), 45,397 reviews were obtained, corresponding to 6,449 establishments. Because the purpose was to examine the effects of the responses for both positive and negative reviews, the selected establishments had to have responded to at least one review and received at least one positive and one negative review. On a scale from one-five stars (i.e., worst to best), positive reviews are those with ratings of four or five stars and negative reviews are those with ratings of one-three stars (Anderson and Han, 2016). This procedure led to a sample of 766 establishments with a total of 9,864 reviews and 1,552 responses. In the sample, 548 establishments rented the establishment as a whole and 218 rented individual rooms.

Table 1 shows the sample description, detailing the number of reviews, number of responses, number of beds, and price per person per night.

Table 1.

Descriptive statistics (766 establishments)

\begin{tabular}{lrrrr}
\hline Variable & Mean & SD & Min & Max \\
\hline Number of reviews & 12.88 & 12.46 & 2 & 181 \\
Number of positive reviews & 10.91 & 11.94 & 1 & 174 \\
Number of negative reviews & 1.97 & 1.50 & 1 & 13 \\
Number of responses & 2.03 & 2.97 & 1 & 48 \\
Number of responses to positive reviews & 0.72 & 2.69 & 0 & 47 \\
Number of responses to negative reviews & 1.31 & 0.88 & 0 & 10 \\
Number of beds & 15.00 & 8.84 & 2 & 68 \\
Price per person per night & 26.87 & 9.33 & 10.70 & 71.69 \\
\hline
\end{tabular}




\subsection{Analyses and measures}

The database preparation was conducted using SPSS 23, and NVivo 11 was used to detect responses expressing gratitude. In particular, NVivo identified all gratitude phrases, such as "Thank you for your review," and "We are really grateful for your words." Of the 1,552 responses, 662 expressed gratitude, corresponding to 303 establishments.

To test the hypotheses, SmartPLS 3.2.9 (Ringle et al., 2015) was applied. Partial least squares (PLS) regressions have been used in different sectors and research settings (Pavlou and Fygenson, 2006; Hernández-Maestro and González-Benito, 2014; Del Brio-González et al., 2018). In SmartPLS 3.2.9, the level of statistical significance of the coefficients was determined through a bootstrap resampling procedure (i.e., 5,000 subsamples, randomly generated). SmartPLS enables PLS multigroup analysis (PLS-MGA) and provides a significance test for the differences across group-specific results.

In the basic model, the dependent variable is the establishment's average rating over the analyzed period (i.e., average rating). The independent variables result from:

- dividing the number of responses to negative reviews by the total number of negative reviews for each establishment [i.e., response (negat)]; and

- dividing the number of responses to positive reviews by the total number of positive reviews for each establishment [i.e., response (posit)].

Two variables were used as control variables based on their potential relationship with average ratings (Shugan, 1984; Melo et al., 2017; Zhang et al., 2020): price and rental type. Price represents the average price per person per night for a standard room and rental type is a dichotomous variable that takes a value of zero if the establishment is rented as a whole and one if the establishment rents individual rooms. For both control variables, positive signs are expected. Regarding price, a company charges a higher price if the quality of its products also is high. Thus, a high price should prompt consumers to expect high quality; if the establishment fulfills or exceeds these customer expectations, ratings will be high. Otherwise, the price would eventually fall (Shugan, 1984; Melo et al., 2017; Zhang et al., 2020). In relation to rental type, establishments renting individual rooms are expected to evoke higher perceived quality because of their entrepreneurs' likely greater commitment to the business, compared with establishments rented as a whole (Melo et al., 2017).

For the multigroup analyses the variable gratitude (negat) results from dividing the number of gratitude responses to negative reviews by the total number of negative reviews. The variable gratitude (posit) results from dividing the number of gratitude responses to positive reviews by the total number of positive reviews. Two groups were created for the gratitude (negat) variable: the low-gratitude (negat) group for establishments where the gratitude (negat) value is below the mean value and the high-gratitude (negat) group for establishments where the gratitude (negat) value is above the mean value. In addition, two groups were created for the gratitude (posit) variable: the low-gratitude (posit) group for establishments where the gratitude (posit) value is below the mean value and the highgratitude (posit) group for establishments where the gratitude (posit) value is above the mean value.

\section{Results}

The results for the basic model (Figure 1) show that responding to negative reviews has a positive effect on establishments' average ratings $(0.145, p<0.01)$, whereas responding to 
SJME

24,2

\section{2}

\section{Figure 1.}

Basic model

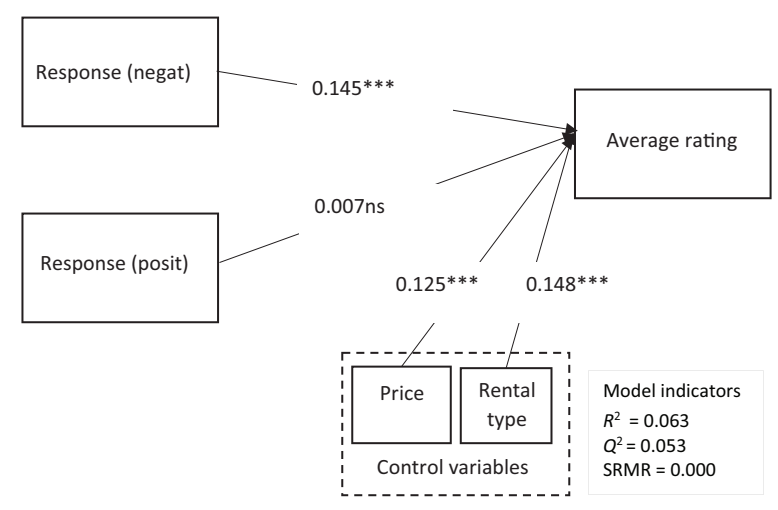

Notes: ${ }^{* * *} p<0.01$; ns: not significant

positive reviews does not have a significant effect on ratings $(0.007, p>0.1)$. Therefore, $H 1$ is confirmed, but $H 2$ cannot be confirmed.

As expected, the control variables have positive and significant effects on ratings. Higher-priced establishments are characterized by higher average ratings $(0.125, p<0.01)$; those establishments that rent individual rooms report higher average ratings than those that rent the whole establishment $(0.148, p<0.01)$. These results support the argument that higher-priced establishments are associated with superior quality and managers of establishments renting individual rooms might engage more in the business and with their customers.

Regarding the predictive ability of the model, the $R^{2}$ value is 0.063 and the StoneGeisser's $Q^{2}$ measure, calculated through a blindfolding procedure with an omission distance of seven, produces a value of 0.053 (models with $Q^{2}$ greater than zero are considered to have predictive relevance). The standardized root mean residual (SRMR), which signifies model fit, is 0.000 .

Multigroup analyses show that expressing gratitude in response to negative reviews positively moderates the relationship between responses to negative reviews and ratings (Table 2), as predicted by H3. The high-gratitude (negat) group is characterized by a positive and significant effect on ratings $(0.243, p<0.01)$, whereas the lowgratitude (negat) group has a weak effect on ratings $(0.080, p<0.1)$. The analyses also reveal that the difference between the effects of response on ratings for the two groups is significant $(0.163, p<0.05)$. Complementarily, Table 3 shows that the use of gratitude responses to positive reviews slightly moderates the relationship between responses to positive reviews and ratings. That is, the difference between the effects for the two groups is significant only at a $90 \%$ confidence level $(0.158, p<0.1)$. For the establishments in the high-gratitude (posit) group, a weak and positive relationship between response (posit) and ratings arises $(0.192, p<0.1)$, whereas there is no relationship between response (posit) and ratings for the low-gratitude (posit) group, providing some evidence in support of $H 4$.

\section{Discussion and implications}

It is still challenging to develop appropriate online response strategies for hospitality businesses. On the one hand, although most research reveals positive consequences of 
response quantity on consumer perceptions and behaviors, some studies do not find significant positive effects (e.g., Mauri and Minazzi, 2013), so additional research is needed, especially for an industry that constitutes a key driver of sustainable rural development. On the other hand, research on the specific characteristics of management responses is still in its early stages. Previous studies seem to indicate that including gratitude statements in responses could have positive effects (Sparks and Bradley, 2017; Mate et al., 2019). However, little is known about the impact of expressing gratitude in responses. In this regard, by using qualitative and quantitative methods, this study furthers understanding of the effects of management responses in the context of rural lodging establishments. It affirms a positive effect on review ratings when companies respond to customer reviews. It also supports a positive effect of expressing gratitude in these responses.

\subsection{Theoretical implications}

This study extends hospitality research that focuses on management responses to online reviews. This study is similar to recent articles about the topic: Xie et al. (2016) and Zhang et al. (2020). First, Xie et al. (2016) and Zhang et al. (2020) include a measure related to ratings as the dependent variable (i.e., ratings increase). Second, though some studies on management responses only focus on responses to negative reviews (e.g., Min et al., 2015; Sparks et al., 2016), Xie et al. (2016) and Zhang et al. (2020) consider all responses. However, neither of these two papers examines the moderating effect that a specific characteristic of the response content (i.e., expressing gratitude) might have on the relationship among management response quantity and review ratings. In this regard, Zhang et al. (2020) examine the direct effect of the use of personalized responses on ratings and Xie et al. (2016) analyze the moderating role that management response quantity has on the relationship among review ratings and revenue. Besides, this study also differs by considering the effects of responses to positive and negative reviews separately.

The results show that the effects of responding to reviews are different according to the valence of the customer reviews. Although responding to negative reviews has a positive effect on the establishment's rating, no effect is obtained from responding to positive reviews. Therefore, responding to positive reviews does not provide additional positive effects beyond those received from the positive customer reviews.

\begin{tabular}{lcccc}
\hline Path & Complete sample & $\begin{array}{c}\text { Low-gratitude } \\
\text { (negat) group } \\
N=560\end{array}$ & $\begin{array}{c}\text { High-gratitude } \\
\text { (negat) group } \\
N=206\end{array}$ & $\begin{array}{c}\text { Difference } \\
\text { PLS-MGA }\end{array}$ \\
\hline Response (negat) - average rating & $0.145^{* * *}$ & $0.080^{*}$ & $0.243^{* * *}$ & $0.163^{* *}$
\end{tabular}

Notes: $* * * p<0.01 ; * * p<0.05 ; * p<0.1$; ns: not significant
Management response to eWOM

273

(1)


In addition, expressing gratitude seems to enhance the effect of responding. However, again, this enhancement outcome is weaker when responding to positive reviews than negative reviews. It is especially rewarding to say thank you when responding to negative reviews. Thus, rural lodging establishments expressing gratitude (with high intensity) in response to negative reviews likely can obtain better ratings than establishments that use this tone less often or do not indicate any gratitude for negative reviews. This finding also applies to positive reviews but to a lesser extent (only at a $90 \%$ confidence level). In this regard, establishments that respond to positive reviews, expressing gratitude with high intensity, create a slight positive link to ratings, though there is no relationship between responding to positive reviews and increased ratings for the complete sample. In fact, for establishments that respond to positive reviews, but scarcely or never express gratitude, responding to positive reviews does not relate to improved ratings.

These findings are congruent with previous literature that shows that responding to negative reviews, vs responding to positive reviews, has a stronger positive effect on hotels' ratings (Anderson and Han, 2016) and RevPAR (Lui et al., 2018). A possible explanation is that negative reviews damage lodging reputation (Nieto et al., 2014). Besides, negative reviews are frequently considered to be especially influential in travelers' decision-making processes (Papathanassis and Knolle, 2011; Casaló et al., 2015).

\subsection{Practical implications}

This research suggests guidelines for establishments with limited resources to especially address negative reviews; they should respond and express gratitude. Responding to all reviews may require a lot of time and effort for rural lodging establishments; responding only to negative reviews offers one strategy to allocate their limited resources more efficiently.

Furthermore, it seems that taking care of the customer in post-purchase stages is rewarding. Thus, it is challenging for businesses to take advantage of this communication channel in support of the business's reputation. For example, in the case of a negative review, responding offers the opportunity to recover from a service failure by providing information about possible external causes or actions that have already been taken to avoid the problem being repeated. Especially in the current competitive environment, rural lodging establishments cannot afford to ignore the challenge of managing eWOM.

In this respect, some establishments might assume they are doing a good job with offline service delivery and that responding to reviews is not important. However, both offline and online signals are important elements. Even establishments that provide high-quality offline service delivery should anticipate potential negative reviews and be prepared to respond to them appropriately.

\subsection{Limitations and future research}

One research limitation of this study is the use of data from one website (i.e., Toprural). Although this accommodation booking website is the industry leader in Spain, it would be beneficial to include additional platforms in further research. Also, continued research might check whether the results would hold with more recent data. 


\section{References}

Akerlof, G. (1970), "The market for 'lemons': quality uncertainty and the market mechanism”, The Quarterly Journal of Economics, Vol. 84 No. 3, pp. 488-500.

Anagnostopoulou, S., Buhalis, D., Kountouri, I., Manousakis, E. and Tsekrekos, A. (2020), “The impact of online reputation on hotel profitability", International Journal of Contemporary Hospitality Management, Vol. 32 No. 1, pp. 20-39.

Anderson, C. and Han, S. (2016), "Hotel performance impact of socially engaging with consumers", Cornell Hospitality Report, Vol. 16 No. 10, pp. 3-9.

Bickart, B. and Schindler, R.M. (2001), "Internet forum as influential sources of consumer information", Journal of Interactive Marketing, Vol. 15 No. 3, pp. 31-40.

Browning, V., So, K. and Sparks, B.A. (2013), "The influence of online reviews on consumers' attributions of service quality and control for service standards in hotels", Journal of Travel and Tourism Marketing, Vol. 30 Nos 1/2, pp. 23-40.

Bughin, J., Doogan, J. and Vetvik, O. (2010), “A new way to measure word-of-mouth marketing”, McKinsey Quarterly, Vol. 2, pp. 113-116.

Casaló, L.V., Flavián, C., Guinalíu, M. and Ekinci, Y. (2015), "Avoiding the dark side of positive online consumer reviews: enhancing reviews' usefulness for high risk-averse travellers”, Journal of Business Research, Vol. 68 No. 9, pp. 1829-1835.

Del Brio-González, E., Hernández-Maestro, R.M. and Yoshikawa, T. (2018), "How does interpersonal justice affect outside directors' governance behavior? A cross-cultural comparison”, Review of Managerial Science, Vol. 12 No. 3, pp. 683-709.

Drollinger, T., Comer, L.B. and Warrington, P.T. (2006), "Development and validation of the active empathetic listening scale”, Psychology and Marketing, Vol. 23 No. 2, pp. 161-180.

Fazal-E-Hasan, S., Mortimer, G., Lings, I.N. and Neale, L. (2017), "Examining the antecedents and consequences of gratitude", Journal of Services Marketing, Vol. 31 No. 1, pp. 34-47.

Filieri, R. and McLeay, F. (2013), "E-WOM and accommodation: an analysis of the factors that influence travelers' adoption of information from online reviews", Journal of Travel Research, Vol. 53 No. 1, pp. 44-57.

$\mathrm{Gu}, \mathrm{B}$. and Ye, Q. (2014), "First step in social media: measuring the influence of online management responses on customer satisfaction", Production and Operations Management, Vol. 23 No. 4, pp. 570-582.

Hennig-Thurau, T., Gwinner, K.P., Walsh, G. and Gremler, D.D. (2004), "Electronic word-of-mouth via consumer-opinion platforms: what motivates consumers to articulate themselves on the internet?", Journal of Interactive Marketing, Vol. 18 No. 1, pp. 38-52.

Hennig-Thurau, T., Malthouse, E., Friege, C., Gensler, S., Lobschat, L., Rangaswamy, A. and Skiera, B. (2010), "The impact of new media on customer relationships", Journal of Service Research, Vol. 13 No. 3, pp. 311-330.

Hernández-Maestro, R.M. and González-Benito, Ó. (2014), "Rural lodging establishments as drivers of rural development", Journal of Travel Research, Vol. 53 No. 1, pp. 83-95.

HomeAway, (2019)“VI Barómetro del alquiler vacacional en España 2019”, available at: www. homeaway.es/info/homeaway-lab/estudios/barometro-alquiler-vacacional/estudio-nacionalmultimedia/estudio/ (accessed September 2019).

Instituto Nacional de Estadística, INE (2019), "Encuesta de ocupación en alojamientos de turismo rural", available at: www.ine.es (accessed September 2019).

Kelley, H. (1973), "The processes of causal attribution”, American Psychologist, Vol. 28 No. 2, pp. 107-128.

Kumar, A. and Epley, N. (2018), "Undervaluing gratitude: expressers misunderstand the consequences of showing appreciation", Psychological Science, Vol. 29 No. 9, pp. 1423-1435. 
Lee, H.R. and Blum, S.C. (2015), "How hotel responses to online reviews differ by hotel rating: an exploratory study", Worldwide Hospitality and Tourism Themes, Vol. 7 No. 3, pp. 242-250.

Lee, Y.L. and Song, S. (2010), "An empirical investigation of electronic word-of-mouth: informational motive and corporate response strategy”, Computers in Human Behavior, Vol. 26 No. 5, pp. 1073-1080.

Li, C., Cui, G. and Peng, L. (2017), "The signaling effect of management response in engaging customers: a study of the hotel industry", Tourism Management, Vol. 62, pp. 42-43.

Libai, B., Bolton, R., Bügel, M.S., De Ruyter, K., Götz, O., Risselada, H. and Stephen, A.T. (2010), "Customer-to-customer interactions: broadening the scope of word of mouth research", Journal of Service Research, Vol. 13 No. 3, pp. 267-282.

Litvin, S.W., Goldsmith, R.E. and Pan, B. (2008), "Electronic word-of-mouth in hospitality and tourism management", Tourism Management, Vol. 29 No. 3, pp. 458-468.

Liu, W. and Ji, R. (2019), "Do hotel responses matter? A comprehensive perspective on investigating online reviews", Information Resources Management Journal, Vol. 32 No. 3, pp. 70-89.

Lui, T.W., Bartosiak, M., Piccoli, G. and Sadhya, V. (2018), “Online review response strategy and its effects on competitive performance", Tourism Management, Vol. 67, pp. 180-190.

Mate, M.J., Trupp, A. and Pratt, S. (2019), "Managing negative online accommodation reviews: evidence from the Cook Islands", Journal of Travel and Tourism Marketing, Vol. 36 No. 5, pp. 627-644.

Mauri, A.G. and Minazzi, R. (2013), "Web reviews influence on expectations and purchasing intentions of hotel potential customers", International Journal of Hospitality Management, Vol. 34, pp. 99-107.

Medallia (2015), "Responding to social media boosts a company's bottom line, new research finds", available at: www.medallia.com/press-release/responding-social-media-boosts-companys-bottomline-new-research-finds/ (accessed July 2019).

Melo, A.J.D.V.T., Hernández-Maestro, R.M. and Muñoz-Gallego, P.A. (2017), "Service quality perceptions, online visibility, and business performance in rural lodging establishments", Journal of Travel Research, Vol. 56 No. 2, pp. 250-262.

Min, H., Lim, Y. and Magnini, V.P. (2015), "Factors affecting customer satisfaction in responses to negative online hotel reviews: the impact of empathy, paraphrasing, and speed", Cornell Hospitality Quarterly, Vol. 56 No. 2, pp. 223-231.

Nieto, J., Hernández-Maestro, R.M. and Muñoz-Gallego, P.A. (2014), "Marketing decisions, customer reviews and business performance: the use of the Toprural website by Spanish rural lodging establishments”, Tourism Management, Vol. 45, pp. 115-123.

Observatorio del Turismo Rural (2017), "Estudio sobre el turismo rural 2017", available at: www. escapadarural.com/observatorio/iv-congreso-europeo-de-turismo-rural-relacion-de-datos-presentados/ (accessed July 2019).

Papathanassis, A. and Knolle, F. (2011), "Exploring the adoption and processing of online holiday reviews: a grounded theory approach", Tourism Management, Vol. 32 No. 2, pp. 215-224.

Park, D.H., Lee, J. and Han, I. (2007), "The effect of on-line consumer reviews on consumer purchasing intention: the moderating role of involvement", International Journal of Electronic Commerce, Vol. 11 No. 4, pp. 125-148.

Pavlou, P.A. and Fygenson, M. (2006), "Understanding and predicting electronic commerce adoption: an extension of the theory of planned behavior", MIS Quarterly, Vol. 30, pp. 115-143. 
Phillips, P., Barnes, S., Zigan, K. and Schegg, R. (2017), "Understanding the impact of online reviews on hotel performance: an empirical analysis", Journal of Travel Research, Vol. 56 No. 2, pp. 235-249.

Proserpio, D. and Zervas, G. (2017), “Online reputation management: estimating the impact of management responses on consumer reviews", Marketing Science, Vol. 36 No. 5, pp. 645-665.

ReviewPro (2015), "2015 Top luxury hotel and brand report”, available at: www.reviewpro.com/reporttop-luxury-hotel-worldwide-rankings-2015-thanks/ (accessed September 2019).

Management response to eWOM

Ringle, C.M. Wende, S. and Becker, J.M. (2015), "SmartPLS 3. Boenningstedt: SmartPLS GmbH", available at: www.smartpls.com

Sen, S. and Lerman, D. (2007), "Why are you telling me this? An examination into negative consumer reviews on the web", Journal of Interactive Marketing, Vol. 21 No. 4, pp. 76-94.

Shugan, S.M. (1984), "Price-quality relationships", in Kinnear, T. (Ed.), Advances in Consumer Research, Vol. 11, Association for Consumer Research, Ann Arbor, MI, pp. 627-632.

Sparks, B.A. and Bradley, G.L. (2017), "A 'triple A' typology of responding to negative consumergenerated online reviews", Journal of Hospitality and Tourism Research, Vol. 41 No. 6, pp. 719-745.

Sparks, B.A., Perkins, H.E. and Buckley, R. (2013), "Online travel reviews as persuasive communication: the effects of content type, source, and certification logos on consumer behavior", Tourism Management, Vol. 39, pp. 1-9.

Sparks, B.A., So, K.K.F. and Bradley, G.L. (2016), "Responding to negative online reviews: the effects of hotel responses on customer inferences of trust and concern", Tourism Management, Vol. 53, pp. 74-85.

TripAdvisor (2015), “5 Tips inspired by our new traveler survey”, available at: www.tripadvisor.com/ TripAdvisorInsights/w661 (accessed July 2019).

TripAdvisor (2019), "Online reviews remain a trusted source of information when booking trips", available at: https://tripadvisor.mediaroom.com/2019-07-16-Online-Reviews-Remain-a-TrustedSource-of-Information-When-Booking-Trips-Reveals-New-Research (accessed October 2019).

Ullrich, S. and Brunner, C.B. (2015), "Negative online consumer reviews: effects of different responses", Journal of Product and Brand Management, Vol. 24 No. 1, pp. 66-77.

Vermeulen, I.E. and Seegers, D. (2009), "Tried and tested: the impact of online hotel reviews on consumer consideration", Tourism Management, Vol. 30 No. 1, pp. 123-127.

Viglia, G., Minazzi, R. and Buhalis, D. (2016), "The influence of e-word-of-mouth on hotel occupancy rate", International Journal of Contemporary Hospitality Management, Vol. 28 No. 9, pp. 2035-2051.

Wali, A.F. and Opara, B.C. (2013), "The impact of customer appreciation service on customer loyalty patronage: evidence from Nigeria financial sector", European Journal of Business and Management, Vol. 5 No. 1, pp. 163-169.

Wei, W., Miao, L. and Huang, Z.J. (2013), "Customer engagement behaviors and hotel responses", International Journal of Hospitality Management, Vol. 33, pp. 316-330.

Willemsen, L., Neijens, P.C. and Bronner, F.A. (2013), "Webcare as customer relationship and reputation management? Motives for negative electronic word of mouth and their effect on webcare receptiveness", in Rosengren, S., Dahlén, M. and Okazak, S. (Eds), Advances in Advertising Research, Vol. 4, Springer Fachmedien, Wiesbaden, pp. 55-69.

Xie, K.L., So, K.K.F. and Wang, W. (2017), "Joint effects of management responses and online reviews on hotel financial performance: a data-analytics approach", International Journal of Hospitality Management, Vol. 62, pp. 101-110.

Xie, K.L., Zhang, Z., Zhang, Z., Singh, A. and Lee, S.K. (2016), "Effects of managerial response on consumer eWOM and hotel performance: evidence from TripAdvisor", International Journal of Contemporary Hospitality Management, Vol. 28 No. 9, pp. 2013-2034. 
SJME

24,2

Ye, Q., Law, R. and Gu, B. (2009), "The impact of online user reviews on hotel room sales”, International Journal of Hospitality Management, Vol. 28 No. 1, pp. 180-182.

Ye, Q., Law, R., Gu, B. and Chen, W. (2011), "The influence of user-generated content on traveler behavior: an empirical investigation on the effects of e-word-of-mouth to hotel online bookings", Computers in Human Behavior, Vol. 27 No. 2, pp. 634-639.

Zhang, Z., Li, H., Meng, F. and Li, Y. (2019), "The effect of management response similarity on online hotel booking: field evidence from Expedia”, International Journal of Contemporary Hospitality Management, Vol. 31 No. 7, pp. 2739-2758.

Zhang, X., Qiao, S., Yang, Y. and Zhang, Z. (2020), "Exploring the impact of personalized management responses on tourists' satisfaction: a topic matching perspective", Tourism Management, Vol. 76, pp. 1-16.

Corresponding author

Rosa M. Hernández-Maestro can be contacted at: rosahm@usal.es

For instructions on how to order reprints of this article, please visit our website: www.emeraldgrouppublishing.com/licensing/reprints.htm

Or contact us for further details: permissions@emeraldinsight.com 